\title{
Seeking Diamond, But Finding Moissanite: A Case Study On Democratic Political Culture In Contemporary Hungary ${ }^{1}$
}

\section{Introduction}

Although since 1990 the indispensable institutional requirements of democracy have been in place in Hungary, studies revealed that Hungarian society in the past 25 years failed to gain sufficiently strong attachment to the norms and values a well functioning democracy requires. Other studies also indicated that these signs, indicating serious shortcomings in democratic political socialization are especially evident in the young generation. In looking for an explanation of this troubling phenomenon political scientists theorised that the low adherence to these values could be the consequence of citizens' low level of activity in voluntary organizations. Could active participation in a voluntary organization reduce the deficits in democratic political socialization? In order to answer this question, this paper set out to examine to what extent the shortcomings of democratic political socialization could be detected among members of a student association ('Depolit') at the University of Debrecen, Hungary.

\section{The institutional requirements of a working democracy}

In their classic work 'The Civic Culture' Gabriel Almond and Sidney Verba have defined democracy as a political system in which ordinary citizens exercise control over elites, that is, when the government is held responsible to the citizenry, or in other words, when citizens can control the government though institutional channels based on mass participation (Almond and Verba 1965: 326). For control over elites be possible, institutional means facilitating such restrictions on governmental power are expected to exist and codified by the legal system. Thus, fundamental human rights must be guaranteed by a legal system independent of the government, suffrage must be universal and equal, the state administration has to be accountable to the parliament whose members must be elected in free, fair and regularly held competitive elections. These requirements and institutional means are indeed indispensable and serve as the 'hardware' of democracy.

\footnotetext{
${ }^{1}$ This paper is a short version of the research report prepared in 2014 within the framework of the 'MYPLACE: Memory, Youth, Political Legacy and Civic Engagement' SSH-2010-5.1-1 FP7 research project
} 
Almond and Verba have also emphasised that a democratic political system must provide opportunities for citizens to participate in decision-making processes and to ensure that the government is held accountable by the citizenry (Almond and Verba 1965: 326). Other scholars have also argued that a democratic political system must provide full opportunities for citizens to represent their interest in a public setting and to channel those into decision making centres (Schattschneider 1960: 141; Dahl 1971; Verba et al. 1978; Barnes and Kaase 1979). Political scientists (Dahl 1971; Verba, Norman and Kim 1978: 1-2; Barnes, et al., 1979) have also emphasised that democracy must provide full opportunities for citizens to manifest their interests through individual and collective action.

\section{A working democracy also requires citizens' attachment to democratic norms and values}

In democratic political systems, it is of crucial importance that citizens have to perceive that the government could be held accountable and that they indeed can channel their interests into the decision-making centres (Finer, 1979; Mason 1995; Reisinger, 1997). Robert Putnam, in his book, 'Making Democracy Work' (1993) pointed out that it is the citizens who can make democracy work. That is, the mere existence of the formal institutional structure of democracy itself neither guarantees that people will be willing to use its institutions, nor ensures that these institutions will be used for the right purpose: to carry out restrictions on the power of governing elites. There are numerous examples in history when institutions of democracy were misused and abused by citizens who showed preference to anti-democratic over democratic norms in their interactions.

To put it bluntly, although the institutional requirements of democracy are indeed indispensable, for a system of democratic institutions to work, the values and norms of democracy requires must be deeply embedded in the citizenry. In their everyday interactions citizens must follow democratic norms, their actions and behaviour must be based on democratic values. Without a democratic political culture, the 'software of democracy', the 'hardware of democracy' the institutional machinery of democracy could not work. 


\section{Democratic political socialization}

However, as McClosky (1964: 375-76) has pointed out, we are not born with democratic values. These elements of the democratic political culture could only be acquired in the process of political socialization. But where can democratic values most effectively be learned? What are the primary spheres of political socialization? In a classical work about American democracy Alexis de Tocqueville emphasised that for democracy to work a number of non-governmental sub-political institutions are also required through which the citizenry can learn democratic values, that is, these organisations can be the schools of democracy (Tocqueville 1966: 485-488). In the field of democratic political socialization several studies has pointed out that there is a tight reciprocal relationship between levels of civic engagement in voluntary organizations and the attachment to democratic values (Stolle and Rochon 1998; Putnam 1993; Brehm and Rahn 1997). The greater trust that citizens hold for others, the more likely they are to participate; the more citizens participate in their communities, the more they learn to trust others. People who participate extensively in their communities are likely to have highly positive beliefs about the helpfulness, trustworthiness and fairness of others. Moreover, there are scholars who argue that trust in other people and democratic institutions go together (Inglehart 1990; Muller and Seligson 1994).

\section{The deficits of democratic political socialization in post-1989 Hungary}

After the establishment of constitutional democracy in Hungary, it was expected that the appropriate environment for democratic political socialization will ensure the increasing attachment of citizens to democratic norms and values. Studies have revealed that Hungarian society in the past 23 years has shown a consistently low level of adherence to the norms of reciprocity and assistance. Members of Hungarian society showed low level of to tolerance; low level of willingness to restrain egocentric behaviour; low level of willingness to engage in cooperation; low level of acceptance of the equitable treatment of others; low level of interpersonal and institutional trust; low level of trust in the horizontal networks of social interaction; low level of respect for the law and high level of dissatisfaction with democracy (Berényi 2001; 2007; Giczi and Sik 2009; Plasser and Ulram 1996). In other words, attachment to democratic values remained consistently low in Hungary. Moreover, in the past 7 years a significant and growing proportion of citizens even started to show preference to non-democratic set of values. These data have clearly indicated the significant shortcomings of democratic political socialization in Hungary. This recent phenomenon has seemed to validate those earlier studies that warned about the 
detrimental effects of the extremely low level of activity of citizens in civil organizations on the democratic political socialization in Hungary (Berényi 1999; 2001).

An international comparative research has found in 2009 that in Europe Hungarians have the second lowest participation and activity rate in civil organizations (Giczi and Sik 2009). Although the number of registered civil organizations has increased in post1989 Hungary, these play insignificant role in the political socialization of the young generation. As Hungarian scholars have pointed out, only a very small fraction, 6-10\% of the young generation is a member of either registered civil organizations or member of communities and $70 \%$ of young people do not even have informal connections to registered civil organizations. Studies have also revealed that the shortcomings of democratic political socialization are even more apparent in the younger generation (Stumpf 1995: 110-121; Szabó and Örkény 1998: 95-128; Gazsó 2003; Csákó et. al 2000).

\section{The research objectives of this paper}

The primary objective of this paper is to examine whether the significant shortcomings of democratic political socialization in the young generation in Hungary could be detected among the members of a voluntary organization formed by political science students of the second largest university, the University of Debrecen. More specifically, the research was carried out to explore how group members relate to the following values: tolerance; reciprocity and assistance; self-restraining of egocentric behaviour; cooperation and compromise; rule of the law; equitable treatment of others; solidarity and interest towards public affairs; trust (personal and institutional). The secondary objective of the research was to explore how Depolit members see significant events in Hungarian history and evaluate the democratic conditions and institutional processes within the institutional framework of the post-1990 Hungarian constitutional democracy.

Several national scale researches in Hungary have indicated that the level of activity of young Hungarians in civil organizations is even lower that of the level activity of the adult population (Gazsó and Laki 2004; Bauer et al, 2005). In 2005, a national scale research found that less than $15 \%$ of young people were a member of organizations in Hungary and only $2 \%$ of them was participating in the activities of the student organization or trade unions (Bauer et al, 2005). 2007 researches on participation of young Hungarians in organizations found that 70 per cent of them have not had any contact with organizations. Those young people who were members of organizations mostly participated in sport associations and student organizations (Gáti 2010).

Considering that, it could be stated that Depolit members belong to the fraction of those young Hungarians who are active members of a voluntary organization. As it was earlier noted, political scientists argue that activity in civil organizations could improve one's attachment to democratic norms and values. The main reason for selecting this group for the subject of the research was that the examination of the 
Zoltán Berényi - Seeking Diamond, But Finding Moissanite: A Case Study On Democratic Political Culture In Contemporary Hungary

level of attachment of Depolit members to these values and norms offered a good opportunity to test this theory.

\section{Methods}

The name of the voluntary organization group is: Depolit (Association of University Students Studying Political Science in Debrecen). The Depolit was founded in 2005 and operated continuously ever since. The number of members of Depolit has fluctuated around 25-30 in the past years. Today the association has 28 members. The association is not affiliated with any political party of Hungary.

Contact with the leadership of Depolit was made in May 2012. However, fieldwork started later than it was originally planned. Instead of July 2012, it has actually started only in September 2012. During the summer of 2012, there was no activity in Depolit. I contacted the leadership of the group in August 2012. They were very approachable. They also showed interest in the participation in the research.

At their invitation, I have participated at their earliest official meeting in September 2012, where I was given the opportunity to introduce the MyPlace EU 7th Framework project to Depolit members. The reaction of the members of the group was supportive. They all agreed to cooperate. They allowed me to be present at their meetings. I was also authorised to make recordings as well. During the course of the research, no serious drawback in cooperation was experienced. The prevailing method of the investigation was participant observation. I have attended their meetings, I was also frequently present at their everyday conversations at the university. I have also conducted a series of semi-structured interviews. All audio records of the semistructured interviews were transcribed. After the collection of data, a qualitative analysis was carried out.

The group has organised numerous successful public meetings and lectures so far at the university; attended a national commemoration of the 1956 Hungarian Revolution in Budapest. They have invited renowned politicians and held shared discussions with them. Members of the group have also participated in discussions and student demonstrations related to the end of 2013 student protests in Hungary.

In order to reveal, to what extent the shortcomings of democratic political socialization of young Hungarians could be detected among the members of Depolit a number of semi-structured interviews were conducted. In agreement with the interviewed persons, their names were fictionalized and in the latter sections of this paper, these fictional names are used. Interviews were carried out to explore the interviewed person's view on the following topics:

- Own participation in Depolit

- The evaluation of the activity of Depolit by the interviewed person

- Links between the interviewed person's own activism and that of his/her parents, siblings, and the extended family. 
- Political heritage/legacies

- Definition of the Hungarian nation

- Norm-breaking behaviour; social justice

- Political institutions and freedom

The preliminary analysis of the data acquired in 2012 has indicated that, one the one hand, members of Depolit show strong attachment to democratic norms and values. On the other hand, results of the data analysis also revealed that Depolit members are very critical of the post-1990 Hungarian political and economic system.

In order to acquire more in-depth information about the basis of that criticism, a subsequent round of semi-structured interviews was conducted. The objective of these interviews was to reveal more details of the views of Depolit members on the democratic conditions and institutional processes of the contemporary Hungarian political system. With this objective in mind, the following themes were explored:

- Critical media

- Civil society

- Civil society participatory environment

- Freedom of speech

- Respect for law

- Access to justice

The University of Debrecen is the second largest university both in size of students and staff in Hungary. It has about 35.000 students. Most of these students are coming to the university from the settlements of Northern and Eastern Hungary, where in the past 24 years the average income of families has been 15-20\% lower and unemployment higher than the national average. The majority of students are coming from lower middle class families that were most hard hit by the 2008 economic crisis. As most of the members of Depolit are studying for a BA in Political Science, they meet almost every day of the week. The also frequently go out in smaller groups during their free time.

\section{Key Findings}

In the following, the main findings revealed by the analysis of the collected data will be outlined.

\section{Participation and activity of Depolit members}

The majority of the members of the group do not participate in other voluntary organisations. Some of them had participated in student organisations in their secondary school. The reasons why the majority of them decided to participate in the activities of the Depolit were that they are all interested in politics and want to get 
Zoltán Berényi - Seeking Diamond, But Finding Moissanite: A Case Study On Democratic Political Culture In Contemporary Hungary

involved somehow in public affairs. Besides, they also want to join a group that would provide good company. As Ilknur put it: 'I think, it is a good thing to be a part of an organisation because this would give you a sense of belonging'. Jenke has also expressed this opinion in a similar way: 'Being a member [of an organisation] is healthier than not being [a member]. I feel I know more about public affairs [because I am a member of Depolit]'.

Although the group has a Facebook page and they are using it for keeping contact with group members, the dominant form of participation in Depolit is face-to-face. Since the majority of the members of the group study political science at the University of Debrecen, they meet almost every day of the week. They also discuss with one another current political events almost every day of the week. More formal meetings of the group are less frequent. The frequency of those formal meetings depends on the actual scheduling of events organised by the group. On average, in every month there is at least one formal occasion when they meet one another. These could be discussions with guests invited by the group, organisational meetings of the Depolit, field trips or participation in important political or social events.

\section{Depolit as an organization in the of eyes its members}

Depolit members generally think that their organization is democratic. There is a formal hierarchy of leadership in the group. Depolit leaders are elected democratically. None of the respondents was able to mention even one occasion when those in the leadership attempted to use their position for personal advancement or tried to force something on the group. They are all convinced that applying democratic principles in the organization and management of the affairs of the group is the best possible method. Depolit maintains contacts with the national level association of political science students. However, according to current Depolit leaders and formal Depolit organisers, this contact has always been very loose and weak. In their experience, those in the leadership of the national association are frequently treating organizations in the countryside with some aristocratic disdain. As a consequence contact with the national association is limited to the leader's occasional visit to the annual meetings in Budapest. Depolit's leadership almost proudly stated that they never received any assistance from the national association, and they do not expect to do so any time in the future.

All interviewed group members emphasised that the democratic atmosphere in the group is very strong. None of the new members have mentioned anything that would have suggested that the older members of the group tend to be distrustful towards them. On the contrary, they emphasised that new members are accepted very easily, and the leadership of the group is very responsive to occasional criticism. They all claimed to be proud members of Depolit. All of them maintained that members of their family clearly approve their participation. Only one member indicated that his 
family is indifferent about his membership. Two of the respondents have mentioned that their family has encouraged them to be a member of other voluntary organizations as well.

All of the respondents said they definitely trust their fellow Depolit members. As Kartal noted: 'Most of us [in Depolit] are good buddies here. If you meet almost every day of the week you get to know each other. Trust? Yes, I trust them, but not blindly, of course'. However, to the question whether their participation in the Depolit increased either the level of their general interpersonal trust, or their trust in institutions in Hungary, none of them answered positively. Tarhos, for instance, when talking about problems in contemporary Hungary has succinctly defined his criteria of placing trust in state institutions: 'People only trust the state and the justice system when they consider to be just and effective. This is not true in Hungary' (Tarhos). This would suggest that the positive experiences accumulated in the participation of Depolit are insufficient for increasing their general trust in people and institutions. Depolit members were also very unconvinced about the importance of their activity for the local community of Debrecen. They frequently mentioned in the interviews that they see Depolit to be an organization that is too small for exerting an effect on the local community of the university or the local society of Debrecen. The opinion of Bars is a typical representation of such view: 'We are a small organization. If I may say so, we are just too small to influence anything, be it either in the university or in Debrecen'.

\section{Depolit members on Hungarian society}

In the interviews, Depolit members have expressed grave concerns about social tensions and problems in contemporary Hungarian society. Several quotes from the interviews clearly indicate this: 'Hungarian society is disintegrating, inequalities are extreme, tensions are very high' (Zovát); Many of the respondents have specifically indicated that they also concerned about the general negative atmosphere they perceived in Hungary: 'Crime rate is very high, people are brutally pessimist, I saw videos in the news and I was horrified [by what I saw]' (Géla); 'There is no trust in the future, nobody smiles on the streets, may be one out of a hundred people is smiling. Only foreigners are happy and smiling” (Arika); 'Teenagers, ... people are depressed, apathetic' (Estilla).

Some of the respondents clearly realized that a more cohesive Hungarian society would require a higher level of interpersonal and inter group trust, and a higher level of tolerance. By arguing that compromise-oriented attitude is preferable, Dele stated: 'being oriented for a compromise would be reasonable. After all, the basis of political democracy is the willingness to reach a compromise. We are all making mistakes sometimes. In this way, we will be able to learn from our mistakes and find better solutions to problems'. Estilla has also pointed out to the desirability of such an attitude: 
Politicians must be able to carry out a compromise with one another. On the other hand, I do not know why people expect that. In their everyday life, they seem to be unable to make compromises. People are very individualistic. Politicians should be a good example for society by showing that they can make a compromise. This could be a positive example for society. It would help the common people to cooperate with one another.

Csenge, talking about the frequent occurrence of selfish behaviour in contemporary Hungary, noted: 'We do not care about one another'. Other members of the group also emphasised: 'People neither trust one another, nor the institutions. The government does not trust the people and I can understand why' (Jenke); 'If my horse died, lets kill the horse of my neighbour as well - that is the common attitude [of the people]' (Kartal); 'The value system is upside down. If a kid gets an F in school his father does not discipline him but goes to the school to beat the teacher' (Ilknur); 'It is our great mistake that they [elites in power] let the Hungarian people to become less intelligent and economic problems are nothing compared to social problems ... and unfortunately, people today [in Hungary] are lazy and passive' (Dele). 'The Hungarian justice system is neither just, not effective and it is very slow. You might rather call it the Hungarian "injustice system".

Today people in Hungary and ... especially young people are extremely passive and this is a bad thing. Everybody is worried about something, people struggle with numerous problems. They keep complaining about everything. However, on the other hand they do not participate in anything, they do not try to resist ... in my view Hungarian society is sick' (Estilla).

One of the most noticeable characteristic feature of such views is that the respondents clearly blame Hungarian citizens for their harmful attitudes towards each other. In none of these views appears the 'the decent people vs the evil state' simplified view. On the contrary: in these typical views the citizens appear as inactive, lazy and unintelligent, who are incapable of understanding that without cooperation they could not possibly hope to change things for the better. These views also reflect the high level of frustration of Depolit members.

All group members have indicated that they despise racism. As Csenge, talking about anti-semitism noted: "When I hear that some idiot people say, "dirty Jew" I feel [so disgusted by that attitude] that I feel I have to vomit'. However, generalised prejudice towards Roma people was also detected among group members: 'Gypsies generally speaking do not want to assimilate to the Hungarian society. They do not want to do that' (Estilla); 'Gypsies learned to speak Hungarian, learned how to read but not to write. They will never - and I mean, a majority of them - write' (Petend); 'Americans and Europeans think that Gypsies are originated from Hungary and this is very frustrating' (Csenge); 
When I have asked them about their reasons behind such statements, all of them brought up numerous negative personal experiences. Ilknur was one of them who was especially emotional:

Gypsies are being discriminated in Hungary? That is simply ridiculous! I grew up on a street full of Gypsy families. We [she and her family] still live there. Don't anyone tell me that they [Gypsies] have not had the same choices to learn ... and now I attend a university ... [but] none of the kids from our street went even to secondary education. The thing is... that they are lazy. I am very irritated, when I hear [from Gypsies] that why should I work, I will rather have one more baby and I will live on social benefits. It disgusts me, because my parents never thought [about] that, they were working in their entire life. And I don't consider myself a racist by saying that.

Her opinion reflects strong statements about Roma people. Her last sentence indicates that she did not realise that regardless of how valid a personal experience might be, it could never serve as a basis for a generalised evaluation of all people in the group. In other words, she did not realise the amount of prejudice hidden in her opinion towards Roma.

The analysis of the data has also revealed a high level of frustration among Depolit members. This attitude on the one hand was primarily related to the perceived weak presence of meritocratic principles: 'If you have enough money, you can commit any crime and you will surely get away with it - as Ferenc Gyurcsány [former PM, who become rich in 1990]. There are no ethical standards [in use in contemporary Hungary]' (Rova). Frustration was also detectable in connection with low level of political efficacy and low level of respect for the law: 'As things are ... today [in Hungary] you can break the law if it promotes your individual achievement - the only thing is that you have to be careful' (Taros). On the other hand, frustration was associated with the feeling of powerlessness and a feeling of being ignorant about how to improve things: 'Parties here see each other not as competitors [for votes], but as enemies trying to destroy one another - it is frightening, they tear Hungarian society apart and I don't know how to stop that' (Estilla); 'People [in a democracy] must not be kept in stupidity. This is certainly not the case in Hungary today though. People are not intelligent enough [and] it serves the interest of politicians. Unintelligent people could be more easily manipulated' (Dele); 'I do not really trust that things will improve, I do not know what to do to improve things' (Géla); 'I don't know how a proper democracy could work really' (Jenke). 'We could not possibly know [from the news] what is happening around us, really. We do not actually know what is happening in the economy' (Arika).

These views indicate that the respondents believe that for a democratic system to work, citizens have to be well informed and intelligent. In the opinion of the interviewed these are primarily required to avoid being manipulated and being turned on one another by the political elites. However, these views also strongly suggest that 
Zoltán Berényi - Seeking Diamond, But Finding Moissanite: A Case Study On Democratic Political Culture In Contemporary Hungary

the responders themselves feel being uninformed and manipulated by the governing elites.

\section{Depolit members on history and political heritage}

All members of Depolit show significant interest in history and political science. However, all of them were very reluctant to give an answer to the question of what periods in Hungarian history would they mark out as good or bad ones. The majority of them used the following argument for avoiding a straight answer: since measuring what is good or bad is relative, as it depends on the value system and knowledge of the respondent, it makes no sense to mark a period in history as a good one. As one of them argued, "What seems to be bad for a 21 st century person was not necessarily considered to be bad for a 14th century person' (Bátor). Although their argument seems plausible at first, but they seemed to forget that there are universal human values by which it is indeed possible to evaluate whether a historical period was good or bad. e.g. being free and living in security is always better than the opposite, no matter of the historical circumstances.

Those who made references to good periods in Hungarian history almost exclusively mentioned the Middle Ages and justified their choice by the greatness of the Kingdom of Hungary. Few mentioned the end of the 19th century as an example, on the basis that it was an era of exceptional economic growth and modernisation. However, it is notable that none of them mentioned either the post-1990 era of constitutional democracy or periods in the 20th century. Some of them clearly stated that the 20th century was a grievous period in Hungarian history. As examples of particular catastrophic events, the Soviet crushing of the 1956 revolution and the Second World War was mentioned several times. Some of the respondents have also referred to the 1950s as the decade of Stalinism and cruel dictatorship in Hungary. As political science students, Depolit members have learned more about the communist era in Hungary than the majority of young people in Hungary. Yet, when having a discussion with them about the communist period in Hungarian history, some of them have not rejected that era of communist dictatorship. As Estilla put it: 'They say that the communist era was terrible, people had fewer rights. But at that time everybody had jobs; you were able to raise your kids. Safety takes precedence over freedom'. Zovát has put it in the following way: 'At that time there were at least full employment, security and order. I feel more sympathy towards the Kádár-era than towards the post-1990 era'.

The fact that (with the exception of Estilla and Zovát) almost all of them preferred to avoid identifying good periods in Hungarian history indicates that their otherwise openly declared attachment to democratic values and norms is not strong enough to apply them to the general evaluation of conditions required for acceptable human existence. In the case of Estilla and Zovát it became obvious when they, not realising 
the interdependent nature of values, clearly declared that they prefer security and order to freedom. This superficial attachment to democratic values and norm became apparent when their evaluation of these values was placed in a historical context.

Many of the respondents indicated that the 'change of the regime' of 1990 is incomplete in Hungary and the corrupt elite of the communist era has managed to reproduce itself in the post-communist era. Some of the interviewed openly claimed that real change has not happened: 'There was no change of the regime in 1990' (Kartal). Another respondent also stated it with high emotional content:

You really believe that there was a change of the regime in 1990? After 45 years of communist dictatorship they changed a flag and proclaimed democracy. Great! I only laugh at people who believe that crap. There was only the change in the methodology [of ruling society], but nothing fundamental has happened (Tarhos)

Yet another member of the group expressed a similar opinion: 'In my village after 1990 the head of the communist agricultural cooperative became the new giant landowner; the former party secretary became the richest man in the village. The top leadership may have changed, but the whole clientelistic structure remained' (Kartal).

\section{Depolit members on the post-1990 Hungarian political system}

As it was already mentioned, practically all members of Depolit study political science or already acquired a degree in political science. They are familiar with the meaning of such notions as: political extremism, liberalism, conservatism, communism, social democracy, and fascism. However, many of them seriously doubted that the main characteristics of contemporary political movements in Hungary could be captured with these notions. Group members were also extremely cautious not to reveal their sympathy towards a particular political party or parties. Statements as 'I would rather not discuss that' (Géla); or 'Let's skip that' (Kartal); 'It is very difficult to express that by using the traditional political scale and terminology' (Bátor) were quite common. As a matter of fact, none of the group members revealed proudly his or her attachment to either of the current Hungarian political parties. It is probably not a coincidence that the majority of them do not like those movies and books that apparently carry intended political messages. In many of the discussions, the subject of how the modern media influence the political beliefs and behaviour of people has frequently came to the surface. When talking about the phenomena of mass emigration of job-seeking young Hungarians to the older member states of the European Union, Csenge has expressed her suspicion about the media: 'I feel that this is... artificially generated both by the media and certain elites ... to make people leave Hungary'. When talking about the typical attitudes of the citizens in Hungary Estilla has also noted: 'I sometimes think that people are intentionally shocked by the media'. 
Zoltán Berényi - Seeking Diamond, But Finding Moissanite: A Case Study On Democratic Political Culture In Contemporary Hungary

The analysis of the data uncovered that they are well aware of the formal, indispensable institutional requirements of democracy. Considering that it is notable that the majority of the respondents are aware that a working democracy requires more than just the presence of the indispensable institutional structure. They clearly expressed their doubts whether the current political system in Hungary satisfies those additional requirements. 'It does not matter, that our constitution is democratic - the government is not for the people, but only for themselves' (Rova). Zovát has put it the following way:

There is a genuine democracy today in Hungary? You must be joking... A well functioning [democratic] state would require a strong middle class, but there is no middle class in Hungary today, only very rich and very poor people. And poor people are especially afraid to protest, because they will lose their jobs.

Taros, expressing a similar view, also noted: 'Yes, you can go to vote - but in reality there is no selection of choice of political parties'. Giving voice to overt pessimism, Bars has also maintained: 'Things are not getting better. Things are getting worse in Hungary. If you look behind the screen, there is no democracy in Hungary - there never was'.

These views not only indicate that they would want a working democracy and see a serious problem of the post-1990 political system falling short of its requirements but also that they are very disappointed because of that. When I asked them about what, in their view, is the main reason that citizens are unable to control governmental elites, many of the respondents indicated that the political elite and political parties in Hungary have much more power and influence than they should have. Many of the Depolit members maintained that although a competitive party system is an indispensable requirement for a democracy, parties exert a very negative effect on the cohesion of Hungarian society and they are looking at parties with aversion for that. The following two citations well illustrate this sentiment: 'Political parties dominate everything in Hungarian society, they want to control everything - everything is overpoliticised and it is disgusting' (Ilknur); 'Parties here see each other not as competitors [for votes], but as enemies trying to destroy one another - it is frightening, they tear Hungarian society apart and I don't know how to stop that' (Arika).

The preliminary analysis of the initial amount of data in early 2013 has indicated that Depolit members have grave doubts about the democratic nature of the post-1990 Hungarian political system. For further investigating the views of Depolit members during the spring of 2013 a subsequent round of data collection was designed and completed. It involved audio-recordings of discussions and semi-structured interviews. The specific objective of these was to acquire more in depth knowledge of the opinions of Depolit members on the democratic conditions and institutional processes of today's Hungary. The results of the analysis of this data will be outlined in the following sections. 


\section{Depolit members on critical media}

The objective of examining this topic was to reveal how Depolit members see that of the major media institutions, how many routinely criticize the government. The dominant opinion of Depolit members was that some important media institutions routinely criticise the government but there are other important outlets that never do: 'Every government has a media of its own that glorifies it, regardless of governmental actions' (Ilknur); 'All government has a media of its own, but this is not good, even those journalists who work for them should not be impartial' (Géla); 'There are media that continuously criticise the government, e.g. ATV, Nepszava' (Bátor).

Some Depolit members also gave voice to their concern about unconditional censorship: 'All government would need a vigorous critique'. (Tarhos). 'If there is a media that nods to everything, that ... endangers appropriate criticism, since it influences the audience' (Csenge).

What we would need is a genuine freedom of speech and opinion. For a proper decision, I would like to know the major motives behind actions. To get to know opposing views on issues would increase transparency and it is also badly needed ... news are always shaped by the view of the journalist. However, the higher the number of available sources [of information] ... the broader the scale of opinions is ... and [media] consumers need those opinions to evaluate those different viewpoints (Arika)

\section{Depolit members on civil society}

The members of the group have several times expressed that in their view in a democracy it would be very important that civil organizations be able to control the governing elites. 'The government should have nothing to do with civil organisations. Civil organisations should control the political sphere. Democracy is about the people and the people should have the opportunity to realise their interest' (Bars); 'Society should be allowed to organise itself as freely as possible' (Tarhos); 'In a democratic political culture it would be best if the widest possible varieties of civil organizations would be able to exist and operate' (Csenge).

The objective of the examination of this topic was to reveal the views of Depolit members on whether major civil society organizations were routinely consulted by policy-makers on policies relevant to their members. Respondents clearly stated that providing opportunities for civil organizations to channel their opinion into decision making centres would be desirable: 'Listening to the voice of the experts would definitely help politicians to draft better policy proposals' (Bars); 'The best thing would be to take into consideration the relevant expert opinions and not political considerations' (Tarhos); 'The important thing would be to allow open channels for 
the opinion of experts to decision-making centres because only in this way could citizens influence decision-making processes' (Rova); 'There are some decisions what society accepts without questioning. If civic organisations would be able to participate in decision-making processes than the transparency of matters would-be improved' (Kartal). Arika pointed out the value of such input for decision-making by claiming:

I disagree with those who say that asking the opinion of numerous civil organisations on issues is not a good thing because it makes decision-making long and difficult. Of course, it is true that these organisations could look at problems from their own point of view. However, judging a problem from different points of view improves our chances to find the best solution for a problem. And they must not forget that there is also a difference of opinions among experts. In any case, finding a good solution for the problems requires examining issues from different points of view.

Depolit members also frequently mentioned that civil society is weak and unable to perform this task in Hungary. The following citation from Ilknur characteristically represents such an opinion:

It is not clear for me that civil organizations in Hungary are weak and die in a relatively short period of time because they lack persistence and do not persevere or because the government kills them? It is not clear to me why is that there is no strong civil society in Hungary, but the fact is, that it is very weak.

Some of the respondents believed that the cause of the weakness of civil society is that governments in post-1990 Hungary prevent them to channel the interest of their members into the decision-making centres. Bars saw in that the continuity of general practice of the communist era: 'In post-communist countries it is very characteristic that previously the state did everything [and] that practice is what is left to us'.

The dominant opinion of Depolit members was that there is a high degree of insulation of the government from societal input in Hungary: 'I don't think that expert civic organisations are able to influence decision-making processes' (Tarhos); 'I think, it will be the best to consider the opinion of those civic organisations which have competence. However, in many cases in Hungary the opinion of those organisations matter which have the most money... and it does not matter that some of them are full of real idiots' (Dele); 'I don't think that it is a good thing when the size and the wealth of organisations and not their expertise determines their ability to influence politicians' (Csenge).

Kartal and Zovát have both expressed their views using sarcasm: 'Well, they surely ask the experts, but in reality, they don't give a shit. I mean, there is no guarantee that the opinion of experts will be taken into consideration' (Kartal); 'Sometimes something 
extraordinary happens: the political leadership becomes curious, what experts might think' (Zovát). Others also expressed similar views: 'There is always something the government refers to, but they do not really take into consideration all expert opinions' (Tarhos); 'Yes of course [they say] that the opinions of civil organizations are taken into consideration, but it does not interest them [the government] really' (Estilla). 'I don't think, that there is an open forum for public discussions in Hungary. However, if these do exist, they do not work. Anyway, the voice of the people is not taken into account' (Arika). 'Government elite only consults with their own people and hardly with others’ (Bátor).

\section{Depolit members on civil society as a participatory environment}

The objective of the examination of this topic was to reveal how Depolit members see the participatory attitude of citizens towards civil society organizations. The dominant opinion of Depolit members was that there are many diverse voluntary associations, political and non political, but the majority of adult citizens are not active in them: 'Civic organisations should be set up voluntarily. If these organisations are set up, but after that nobody is active in them, then in reality, they don't do anything' (Kartal). 'Unlike in Hungary, people in Western Europe are more active in civic organisations' (Arika).

It was just yesterday that I happened to see statistical information on that. According to that, young people in Hungary between the age of 18 and 29 are not active at all. This is a sad thing, because this would be the generation with the highest activity. Usually, after people get older than 29 years, they start a family and [their] family will take up most of their time (Bars).

In general, we see in Hungary today that the political parties dominate everything in society. However, the reason for that is that people are passive. Most of them are not interested in public affairs and even if they do, they don't do anything for the establishment of a really democratic state (Csenge).

Depolit members would favour a situation when there are many diverse voluntary associations, political and non adult citizens to be at least occasionally active in at least one of them, if not more. In the following, quotes are provided to illustrate some of their views: 'Having a dense network of civic organisations improves social cohesion. In addition to that, life is more stimulating in such a society. A dense network of civil organizations also improves people's tolerance' (Dele); 'Democratic political socialisation would require people to be active in these organisations' (Tarhos). 


\section{Depolit members on freedom of speech}

The objective of the examination of this topic was to reveal what Depolit members think about freedom of speech in Hungary, more specifically, the opportunities for citizens to discuss openly political issues in private homes and in public spaces. Depolit members were all aware of how indispensable is the freedom of speech in a democracy. As Kartal noted: 'Expressions of political opinions should be fully respected by the government. Freedom of speech among private citizens in their homes and in public spaces must not be restricted for any criticism to appear openly'.

The dominant opinion of Depolit members was that there are minor restraints on the freedom of expression in the private sphere, but these are predominantly limited to a few isolated cases or only linked to soft sanctions. However, as a rule, there are no interventions and prohibitions on political statements coming from the government in contemporary Hungary. By representing a different perspective, Bars stated: 'Well, retribution of discussions is a concept invented specifically for Hungary'. Rova also claimed: 'Yeah, you can tell anybody your opinion but that is all. I mean, nobody cares about people's opinion'. Estilla expressed her view on that with less sarcasm: 'Contrary to what is it today in Hungary, it would be best for people to be able to speak openly and without fear of any retribution. This is an indispensable requirement of a genuine democracy'. Bátor also expressed his opinion on the subject in a more elaborate manner:

If someone stands up for his/her political opinion nowadays in Hungary, then what usually happens is that this man is left alone. I mean, the authorities will not bother him. Nevertheless, on the other hand, sometimes it happens that such a person is persecuted by the tax authorities and the government tries to make his/her life more difficult'.

\section{Depolit members on respect for law}

The objective of the examination of this topic was to reveal whether in the views of group members, public officials are impartial and respect the law in the performance of their functions. In the discussions respect for the law was understood as the effective control of public servants so that policy implementation in individual cases could be characterized by impartiality whereas undue bias and corruption could be sanctioned.

The dominant opinion of Depolit members was that equality before the law is an extremely important condition for a working democracy: 'Equality before the law would be extremely important. The court should provide the same rights for its citizens regardless whether they are wealthy or not' (Tarhos); 'Politicians are making the law. So it would be a very nice thing if they would also respect the law' (Arika); 'I 
reckon, the most important thing would be to prevent the corruption of judges. If the courts are corrupted, everything goes down the drain. If there is no equality before the law, there is no rule of the law' (Dele).

However, in their view this is not the situation in contemporary Hungary. In their opinion, the law is weakly respected by both politicians and the public officials. This view was clearly expressed by Bátor:

Yeah, corruption in public administration is rampant. I mean, if by corruption we also mean giving a job to my relative... then of course, there is corruption [in Hungary]. On the other hand, I believe that corruption in public administration is done without the direct involvement of money'

In their view corruption and discriminatory practices are common in most parts of the public administration: 'I reckon, there is corruption to a great extent in public administration in Hungary today. What is worse, it is ever-growing' (Estilla); 'Today in Hungary you can buy anything with money. I don't think that the law is respected fully by public officials. There is corruption in public administration, there could be no question about that' (Ilknur); 'This is one of the worst things in Hungary today' (Tarhos); 'Public servicemen take into consideration the respect for the law but only to a very small degree' (Askam). 'People without money and influence are not able to bribe the prosecutor, or the judge. If we could eliminate corruption, people who are not so well off would have a better chance to receive justice in Hungary' (Torzon).

\section{Depolit members on access to justice}

The objective of the examination of this topic was to reveal how Depolit members see the extent to which trials are fair, citizens can bring cases before the courts without risk to their personal safety, and citizens have effective ability to seek redress if the public authorities have violated their lawful rights, including the rights to counsel, defence, and appeal as well as presumption of innocence and protection from ex post facto laws. The analysis of data revealed that Depolit members are well aware of how indispensable is to provide citizens access to justice. As Csenge put it: 'The justice system must operate on the basis of equality before the law. It would be crucially important that citizens will be able to seek legal redress at the court effectively and quickly'; 'There are other countries where the justice system is working and things are in general much better than in Hungary. And I don't think, that it is a coincidence' (Kartal).

The dominant opinion of Depolit members was that access to justice is mostly respected by the public authorities, but at the same time citizen's means of effective petition and redress are limited by the slow operation of the court system: 'One thing is for sure, the operation of the Hungarian justice system is very sluggish' (Dele). In the following, a few quotes are provided to illustrate some of these views: 
The justice system is basically independent from the government, but again, there are those cases when one can see that this is not entirely true. I would prefer the American justice system. Also, the Hungarian justice system is extremely sluggish in operation. Why are they not able to make a decision in a relatively short time even in simple cases?’ (Bars).

Ilknur also stated that: You can buy anything with money. Decisions are not biased, but to say that in Hungary today the court system operates effectively would not be true. There are extremely lengthy trials'. Others pointed out to the fact that anyone could be kept in arrest for years while waiting for trial: 'I don't reckon, that the Hungarian justice system is effective. One is forced to wait in arrest for two and three years for trial. To call that ineffective is an understatement' (Estilla). Arika has also pointed out to the scale of bureaucracy that people seeking justice have to overcome: 'I don't think, that there is a chance of making the idea of a corruption free justice system a reality in Hungary. There must be much less bureaucracy. Today the court system in Hungary is too complicated'.

\section{Conclusions}

In the field of political socialization several scholars pointed out that we are not born with democratic values (McClosky 1964; Putnam, 1993; Muller and Seligson 1994; Plasser and Ulram 1996). Therefore, for the institutions of a democratic system to work, people must gain attachment to democratic values and norms. Citizens have to learn to tolerate existing differences in society; they have to understand that since democracy requires complex obligations they must not, in all circumstances, try to follow only their own self-interest. In other words, they have to learn to exercise selfrestraint and to appreciate the value of mutually beneficial cooperation. Citizens must also have to learn to value the rule of the law, solidarity and the equitable treatment of others. They have to learn to appreciate those who not only show active interest towards public affairs but who are also inclined to be active in their community. They have to learn to value not only their own freedom, but also those conditions that provide opportunities for freedom for their fellow citizens in society. For a working democracy, people also have to trust one another and the institutions of democracy to the extent that is sufficient for making them willing to use those institutions for resolving their interest conflicts. Citizens also have to learn to appreciate cooperation through competition. Political scientists also argue that activity in civil organizations could improve one's attachment to democratic norms and values (Putnam 1993; Muller and Seligson 1994; Misher and Rose 1997; Reisinger 1997; Csákó et. al. 2000). The examination of the level of attachment of Depolit members to these values and norms offered a good opportunity to test the validity of this concept. 
The analysis of data collected indicated that Depolit members show signs of higher attachment to democratic norms and values than average young Hungarians. While intolerance and prejudice against minorities have increased in recent years in Hungarian society, Depolit members despise racism and discrimination and emphasize the benefits of tolerating differences. Similarly, while Hungarian society shows very high level of individualism, low levels of willingness to restrain egocentric behaviour and low levels of readiness to engage in cooperation, Depolit members clearly see the value of cooperation, reject the passivity of Hungarian citizens and blame them for being too individualistic, selfish and not being sufficiently active in public affairs. They also strongly attach importance to the value of equality before the law, and the equitable treatment of others. While in Hungarian society law abidance is very low, Depolit members strongly reject anti-meritocratic principles and law breaking behaviour and they apply democratic and meritocratic principles in the management of their association.

This study has also found however, that some of the typical signs indicating superficial democratic political socialization could also be detected in the case of Depolit. This superficial attachment to democratic values and norms had become apparent when they were asked to identify good periods in Hungarian history. Almost all of them preferred to avoid doing this by referring to the contingent nature of values and norms. Although values and norms are not the same in every culture and historical period, nevertheless, there are fundamental human values that must be respected in every culture and in every historical period. This reluctant attitude indicates that their attachment to democratic values and norms is not strong enough to apply them to the general evaluation of conditions required for acceptable human existence.

Their unsound adherence to these values also became manifest when some group members openly expressed generalised distrust towards Gypsies and stressed that they do not consider themselves to be intolerant because of that. Interpersonal trust within the group is high, new members are easily accepted. Group members also trust their elected leaders. On the other hand, however, it seems that this high level of in-group trust at micro-societal level is not enough for group members to acquire generalized interpersonal trust at the macro-societal level. Could it be that discouraging experiences in macro-societal level prevent the induction of generalized interpersonal and institutional trust? To answer that question would require additional research.

Yet another indicator of their superficial democratic political socialization is that although they stress the importance of activity in public affairs, they do not believe that through the series of ongoing small-scale activities, significant large-scale changes could be achieved in society. Perhaps it is not a coincidence that they do not believe that the activity of their group could exert any effect on either the student community of the university or the local community of the city of Debrecen. Their activism is limited to organizing public talks, discussing political issues among themselves and commemorating significant national events. Their distrust in the efficacy of organised public action became apparent in December 2013. For weeks, students at all universities and secondary schools were protesting all over in Hungary. Despite the fact that many of the Depolit members were participating at the student protests, they 
Zoltán Berényi - Seeking Diamond, But Finding Moissanite: A Case Study On Democratic Political

have not even considered using their organization to support the case of students. Also, when talking about the cause of the low level of activity of Hungarian citizens in public affairs they almost exclusively referred to the detrimental conditions and restricted opportunities for participation. While those conditions indeed do not foster participation in contemporary Hungary, blaming the conditions alone and ignoring people's subjective attitude of passivity is surely a one-sided approach and serves to ignore the responsibility of citizens.

This study has also found that none of the group members see the post-1990 era of constitutional democracy to be a good period in Hungarian history. None of them mentioned membership in the European Union to be a momentous achievement for the country. Some of them even would prefer job security to freedom and, as a consequence, would prefer the late communist era to the current political system.

Group members also strongly criticise the contemporary democratic political system. None of them echoed the mistaken but widespread view in Hungarian society that the plurality of political parties and the presence of free elections are sufficient for a political system called democracy. Many of them claimed that since this political system does not work as a democracy it should not be called that. However, none of the group members would prefer a dictatorship to a democracy and would not support a political party aiming to establish that.

This general opinion of Depolit members is yet again a sign of their commitment to democratic norms and values. And it is this commitment is a basis of their criticism of the contemporary political system. As a matter of fact, many of the group members see the post-1990 political system in Hungary as a kind of continuation of the previous communist dictatorship. They see it as a corrupt, closed elitist system, which does not give opportunities for genuine participation in the decision-making processes. Their opinion brings into perspective the words of David Mason (1995: 385) who after the establishment of constitutional democracies in Eastern Europe has argued that

... participation and representativeness are important aspects of democratic politics in established democracies and probably even more so in fledgling ones... since democratic legitimacy and stability can probably be maintained only if the governments remain broadly responsive to and representative of the populations - or at least be perceived as such.

It became evidently clear from the analysed data that the majority of Depolit members do not perceive the government in that way. In analysing the conditions required for the mechanism of system-justification to work, that is, when citizens are feeling motivated to defend and support a political system that is disadvantageous for them John T. Jost (2003: 284) has argued, that people only continue to accept the current system of decision-making until they believe that it offers them at least some 
believable opportunity to participate in those processes. In the light of the data analysed, the majority of Depolit members already seem to have passed that threshold.

\section{References}

Almond, G. - Verba, S. (1965): The Civic Culture. Political Attitudes and Democracy in Five Nations. Little Brown and Co, Boston

Barnes, S. - Kaase, M. (1979): Political Action: Mass Participation in Five Western Democracies. Sage, Beverly Hills

Bauer, B. - Ságvári, I. - Szabó, A. (ed.) (2005): Youth 2004. Young Hungarians research report. Mobilitás Office of Youth Research, Budapest

Bauer, B. - Szabó, A. (ed.) (2005): Youth 2008. Flash report. Institute for Social Policy and Labour, Budapest

Berényi, Z. (1999): Constitutional Democracy and Civil Society in Post-Communist Hungary. Hungarian Academy of Sciences - IPS, Budapest

Berényi, Z. (2001): Democratic Values and Civic Culture in Hungary. Hungarian Academy of Sciences - IP,: Budapest

Berényi, Z. (2007): 'Weak Civic Culture in Hungary: an Examination of Some Consequences of Economic Inequality'. In: B. Sanghera - S. Amsler - T. Yarkova (ed.): Theorising Social Change in Post-Soviet Countries - Critical Approaches, Oxford - New York, Peter Lang, pp 135-153.

Brehm, J. - Rahn, W. (1997): 'Individual-Level Evidence for the Causes and Consequences of Social Capital'. American Journal of Political Science, 41(3): pp 999-1023.

Csákó, M. - Berényi, E. - Bognár, É. - Tomay, K. (2000): 'Politikai szocializáció Magyarországon a kilencvenes években' [Political socialization in Hungary in the 1990s]. Szociológiai Szemle 1. pp 50-68.

Dahl, R. (1971): Polyarchy: Participation and Opposition. Yale University Press, New Haven

Finer, S. E. (1979): Comparative Government. Allen Lane, London

Gáti, A. (2010): Aktív állampolgárság Magyarországon nemzetközi összehasonlításban (Active citizenship in Hungary in international comparison), TÁRKI, Budapest

Gazsó, F. (2003): ‘Pártpreferenciák generációs metszetben', In: Bőhm, A. - Gazsó, F. Stumpf, I. - Szoboszlai, Gy.: Parlamenti választások 2002. MTA PTI - Századvég, Budapest, pp 67-76.

Giczi, J. - Sik, E. (2009): Bizalom, társadalmi tőke, intézményi kötődés (Trust, social capital and social attachment). In: Európai Társadalmi Jelentés (European Social Report). Budapest, TÁRKI, 2009

Inglehart, R. (1990): Culture Shift. Princeton University, Press Princeton, N.J.

Jost, J. T. (2003): Önalávetés a társadalomban: a rendszerigazolás pszichológiája, Budapest, Osiris

Mason, D. (1995): 'Attitudes toward the Market and Political Participation in the Postcommunist States’. Slavic Review 55(3) pp 385-407. 
Zoltán Berényi - Seeking Diamond, But Finding Moissanite: A Case Study On Democratic Political Culture In Contemporary Hungary

McClosky, H. (1964): 'Consensus and Ideology in American Politics'. American Political Science Review 58. pp 361-382.

Misher, W. - Rose, R. (1997): 'Trust, Distrust and Skepticism: Popular Evaluations of Civil and Political Institutions in Post-Communist Societies'. The Journal of Politics, 59:2. pp 418-451.

Muller, E. - Seligson, M. (1994): 'Civic Culture and Democracy: The Question of Causal Relationships'. American Political Science Review, 88 pp 635-652.

Plasser, F. - Ulram, P. (1996): 'Measuring political Culture in East Central Europe. Political Trust and System Support'. In: Plasser, A. - Pribesky, A. (ed.): Political Culture in East Central Europe. Aldershot, Avebury pp. 3-35.

Putnam, R. at al. (1993): Making Democracy Work. Civic Traditions in Modern Italy. Princeton University Press, Princeton, N.J.

Reisinger, W. (1997): 'Establishing and strengthening democracy'. In: Robert D. Grey (ed.): Democratic Theory and Post-Communist Change. Prentice Hall, Boston, N. J.pp 52-74.

Schattschneider, E. F. (1960): The Semi-Sovereign People: a Realist View of Democracy in America. Rinehart and Winston, New York

Stolle, D. - Rochon, T. M. (1998): 'Are all associations alike?'. The American Behavioral Scientist (September 1998) pp 47-65.

Stumpf, I. (1995): 'Ifjúság, politikai részvétel, pártpreferenciák' [Youth, political participations and party preferences]. In: Gazsó, F. - Stumpf, I. (ed.) Vesztesek. Ifjúság az ezredfordulón [Losers. Youth at the Millennium]., Ezredforduló Alapítvány: Budapest pp 110-121.

Szabó, I. - Örkény, A. (1998): Tizenévesek állampolgári kultúrája. [Civic culture of Teenagers.] Budapest, Minoritás Alapítvány.

Tocqueville, A. (1966): Democracy in America. In: J. P. Mayer - M. Lerner (ed.). Harper \& Row. New York-Evaston-London

Verba, S., - Norman, N. - Kim, J. (1978): Participation and Political Equality: A SevenNation Comparison. University of Chicago Press, Chicago 